\title{
The Impact of Operating Cash Flow in Decision-Making of Individual Investors in Vietnam's Stock Market
}

\author{
Dung Duc NGUYEN ${ }^{1}$, Cong Van NGUYEN ${ }^{2}$
}

Received: February 27, 2020 Revised: March 08, 2020 Accepted: April 10, 2020

\begin{abstract}
The paper examines the impact of information about cash flow from operating activities of firms listed on Vietnam's stock market to the decision making of individual investors. Data were collected from interviews with 160 individual investors about their investment decisions based on information on profit growth and cash flow growth from operating activities. T-test was conducted to research on Vietnam's stock market - a market considered as information that is not really public, transparent and ineffective. The research results show that: (1) investors do not care about cash flow from operating activities when making investment decisions if the company's profits grow positively, (2) information about cash flow from operating activities only affects the decisions of individual investors once profit growth is negative, and (3) conflicting information between profit growth and cash flow growth from business activities significantly affects the confidence and comfort of investors in Vietnam's stock market when they make investment decisions. Then, the study points out the mistake of investors when making investment decisions, and offers recommendations to investors when making investment decisions, not only concerned with profit growth, but also paying special attention to cash flow growth, especially cash flow from the company's business operations.
\end{abstract}

Keywords : Decision Making, Individual Investors, Operating Cash Flow, Operating Cash Flow Growth, Profit Growth

JEL Classification Code: D81, G11, G41

\section{Introduction}

Vietnam's stock market is a nascent market, newly developed at an early stage with an asynchronous and incomplete legal system. Not only the market is young, but most investors still lack substantial knowledge, skills and experience. With a new market at an early stage and based mainly on individual investors, like in Vietnam, investor psychology and understanding have a strong impact on the stability of the market.

\footnotetext{
${ }^{1}$ First Author. School of Accounting and Auditing, The National Economics University, Vietnam. Email: dungnd2141@gmail.com ${ }^{2}$ Corresponding Author. Professor, School of Accounting and Auditing, The National Economics University, Vietnam. [Postal Address: 207 Giai Phong Road, Dong Tam Ward, Hai Ba Trung District, Hanoi, 116000, Vietnam] Email: anhcongtuan@gmail.com

(c) Copyright: The Author(s)

This is an Open Access article distributed under the terms of the Creative Commons Attribution Non-Commercial License (http://Creativecommons.org/licenses/by-nc/4.0/) which permits unrestricted noncommercial use, distribution, and reproduction in any medium, provided the original work is properly cited.
}

Due to limited knowledge, investors' reactions are always passive in the movements of the stock market. Therefore, to avoid fluctuations in Vietnam's stock market, to help individual investors be confident and comfortable when making investment decisions, the provision of relevant financial information - including information cash flow is very important and necessary.

Most studies have recorded the role of information about cash flow for information users, including investors. This research acknowledges the critical usefulness of this information to investors. However, in reality, although appreciating the role of cash flow information for investors, there is very little research on investor behavior regarding information about cash flow, whether the investor's decision is based on information about cash flow or not. For a fairly effective and transparent information market, investors will be responsible for the financial information that businesses provide. On the contrary, for a market like Vietnam, it is difficult to assert that investors have actually used information about cash flows in particular and other financial information announced by enterprises to make business decisions. 
Information about a company's cash flow includes cash flow from operating activities, cash flow from investment activities and cash flow from financing activities; attention to operating activities is key because cash flow is related to activities that generate revenue or major income of a company. Cash flow from operating activities provides basic information to assess the ability of businesses to generate cash from operating activities to cover debt, maintain operations, pay dividends, and carry out investment activities without external financial resources.

Our selection of the impacts of operating cash flow on individual investors' decision-making, the research topic of this paper, is based on the following aspects:

- Regarding the size of individual investors in Vietnam. In Vietnam, individual investors account for $99 \%$ of the current market. According to the latest statistics of the Securities Depository Center, the number of individual investors has reached more than 1,800,000 accounts, while the number of institutional securities investment accounts has fallen to just over 8,000 accounts (Passionate investment, 2019).

- Regarding the concerns of individual Vietnamese investors. Unlike institutional investors, individual investors often focus only on seeking lightning or surfing opportunities. Therefore, most of the time they spend on monitoring trading boards, monitoring current stock prices, reading news, and listening to information through forums, individual investment groups, etc., but very little reliance on market research and analysis. Investments by individual investors often follow the public's buying trend and the trend of "not buying yet, but worried about selling". Therefore, investing in securities in Vietnam is potentially risky, especially for new entrants.

- Regarding the psychology of individual Vietnamese investors. Investor sentiment on the stock market reflects their attitude towards market movements. Due to the characteristics of culture, lifestyle, education and psychology of individual investors in Vietnam, they also bear common psychological characteristics of the nation. These psychological traits are: (a) overconfidence, outrageous optimism or pessimism, (b) regrets, (c) herd mentality, (d) preservation, and (e) reliance on experience (Nguyen, 2016).

Overly optimistic psychology triggers people's attitude of "disregard", when faced with insurmountable barriers, investors easily have feelings of pessimism, boredom or extreme vulnerability, and easily engage in activities even if the business is losing money and they don't know where to stop. Regret psychology dominates the decisions of investors, causing them to make investment decisions emotionally and without basis. The herd mentality, following the crowd due to inexperience and unprofessionalism, lack of transparency in financial market information, uncontrolled insider trading, etc., will cause panic on the financial market. Conservative psychology, not wanting to lose money, makes investors distrust financial policies, and so they always find a way to deal with financial policies as long as it benefits them. Experienced psychology makes investors good at imitating, following, less likely to be creative and interested to follow a path that will make it difficult to deploy new financial instruments.

\section{Literature Review}

Research on the influence of cash flow on investor decisions is limited. Imhof and Seavey (2018), Oh and Shin (2019) examined the importance of investors' cash flow and earnings forecast. The results show that investors are more interested in cash flow forecasting information for economic decision-making. Yeo (2018) studied the role of free cash flow in making investment decisions and dividends decisions in the shipping industry, showing that free cash flow (FCF) of shipping lines of different sizes affects investment and dividends. FCF is a determining factor for investments and dividends. Larger FCF leads companies to increase investment and reduce dividends. Studying the use of income and cash flow in pricing and investment decisions in the United States and Mexico, Miranda-Lopez and Nichols (2012) show that the majority of US investors rely on income, while most investors in Mexico rely on cash flow. The results also show that investors can be unpredictable; they do not consider using any information measures to make decisions, especially those investors focused on using income information instead of cash flow.

Lau and Mahat (2019) conducted research on the different roles of cash flows in assessing the return on investment in the Association of Southeast Asian Nations (ASEAN) suggesting that companies should manage cash flow prudently in considerations of firm value from the shareholder's perspective, measured directly using stock return. Cash returns on assets will become an important performance indicator for the company, while higher cash component over reported earnings is preferred. Aoun and Hwang (2008) researched the impact of cash flow and firm size on investment decisions of US information technology and information technology companies listed on the NASDAQ stock exchange. They indicate that all companies are sensitive to the availability of internal funds; investment intensity decreases by firm size and leverage have a negative impact on investment for ICT companies. Melander, Sandström, and Schedvi (2017) study the impact of cash flow on investment and find that cash flow has a positive effect on investment, and that the efficiency of cash flow is enhanced for companies with limited financial resources.

Some studies mention the role of other factors in decision-making such as the role of financial information, 
behavioral trends, herd mentality, overconfidence, heuristics, risk aversion, corporate governance and experience, etc. Zager and Zager (2006) refer to the role of financial information in the decision-making process. The study emphasizes the existence of quality information, including accounting information and information from financial statements. The study also emphasized the requirement that users of information - including investors - must know how to read those reports. Rasheed, Rafique, Zahid, and Akhtar (2018) examines the impact of the two most commonly used heuristics, namely, representative bias and availability bias in making investment decisions, looking at whether either locus of control sites interacting with the relations was based on theoretical proposals or lack of evidence. The results show that both of the research methods studied led investors to deviate from rational decision-making, while the control position had no significant censorship effect. Mumtaz, Saeed, and Ramzan (2018) studies factors that influence investment decision-making in the Pakistani stock market such as heuristic, risk aversion, financial tools and techniques, firm's corporate governance, and day-to-day experience with the decision making of the investor. Research results show that heuristics, risk aversion, financial tools and techniques have a significant positive effect, and day-to-day experience and corporate governance play an important role in the investment decisions of the investors. Nguyen, Dang, and Pham (2020) when studying the effects of overconfidence and cash flow on investment in Vietnam, have shown that the overconfidence of CEOs has a positive impact on investment. The results also indicate that firms with overconfident CEOs and large cash flows tend to invest less than firms with low cash flow.

According to Ward and Foster (1997), cash flow from operating activities is forecast two years before firms are in financial difficulties. However, the authors provide evidence that cash flow from investment and finance activities has a more limited role in predicting financial difficulties than operating cash flow. In support of the perception, Gomez (2002) argues that operating cash flow is the most important factor in predicting the financial crisis; however, if operating cash flow is positive while cash flow from investment and financial activities are deeply negative, businesses will also face difficulties in their financial situation. Operating cash flows also help to provide a perception of their life cycle. Investing in firms that are growing might bring very high profits in the future, while investing in firms about to be hit by recession will bring risks to investors. A firm goes through four stages in its life cycle: introduction, growth, saturation and recession. It can be seen in the perceptions of Jooste (2011), Dickinson (2011).

Introduction. When the business is newly established. During the introductory phase, high product development and marketing costs and relatively low sales often result in negative cash flow from operating activities and profit. Growth. During the growth period, the net cash flow from operating activities increases, the cash flow from financial activities is positive. Saturation. During this period, cash flow from operating activities is still high, cash flow from investing activities starts to decrease, as does cash flow from financial activities, due to the repayment to investors or high dividend payments. Recession. When cash flow from operating activities gradually decreases, cash flow from investing activities can be converted from negative to positive when a firm liquidates assets, and the cash flow from financial activities is usually negative as it continues to repurchase stocks, repay bonds and bank loans.

Next are related studies that compare the role of cash flow information with profit information provided to users. McEnroe (1996) evaluates the business performance of firms since their business performance reports will give more accurate results than cash flow statements. Clinch, Sidhu, and Clinch (2002) interestingly point out that the decline in cash flow from operating activities will be one of the signs of the business recession in its profits in the following years. According to Nguyen and Tran (2014), the special cash flow statement following the direct method enhances the firm's ability to forecast data on its business performance as well as future cash flows.

Arguing that the role of information provision of these financial statements should not be compared, Kallunki and Paakki (2005) identify a relationship between prices in the stock market and data on cash flow and profit. The authors' research of 165 firms in 19 European countries shows that it is impossible to assess that data provided in cash flow statements or income statement have a greater influence on the stock price of firms, whose information complements each other to support stock prices, or assess the prospects for business growth.

Most studies related to providing information on cash flow from operating activities are conducted in developed countries, while there is very little research on developing countries like Vietnam, with ineffective markets. Vietnam stock market is considered an ineffective information market because the economy does not originate from the private economy like it does in developed countries; the stock market has only recently developed. Especially, the study of cash flow from operating activities aims at providing information to individual investors, who play an increasingly important role in the stock market. Research on cash flow from operating activities at firms listed on the Vietnam stock market in providing information to investors may differ greatly from other studies in developed countries for a variety of reasons.

\section{Hypothesis, Data and Research Methods}

\subsection{Research Hypothesis}

To compare the difference in investor's decision, T-tests were used, while there is opposite information between cash 
flow from operating activities and profit. From the business performance report, T-tests will be compared to test the following hypotheses:

H1: There is no difference in investors' decision-making on positive and negative signs of cash flow from operating activities when the firm's profit grows.

H2: There is no difference in investors' decision-making for positive and negative signs of cash flow from operating activities when the firm's profit is negative.

T-tests will make comparisons. In the first case, comparing Firm A, having a positive profit and positive cash flow from operating activities, with Firm C, having a positive profit, but negative cash flow from operating activities. The second case, the test compares Firm B, having a negative profit and negative operating cash flow, with Firm $\mathrm{D}$, also having a negative profit, but positive cash flow from operating activities.

\subsection{Research Data}

The questionnaire is divided into Questionnaire No. 1 and Questionnaire No. 2. Eighty investors will receive Questionnaire No. 1 and 80 investors will receive Questionnaire No. 2. The investors selected are shareholders in the firms listed in the Vietnam stock market. Investors were surveyed independently from each other, one questionnaire for each. In the survey, $58 \%$ of the respondents were male. The age group 26 to 35 was the largest age group, accounting for $47 \%$ of respondents; the age group 36 to 45 accounted for $33 \%, 13 \%$ of respondents were under 26 , and $7 \%$ were over 46 years old. The research also shows that $65 \%$ of the responding investors have a university degree or higher, and $23 \%$ have university and college degree. The majority of investors, accounting for $79 \%$, have more than three years of experience in securities investment.

\subsection{Research Design}

Questionnaire No. 1 includes two financial statements of Firm A and B. Firm A in the Questionnaire is a firm with positive profit from the income statement with a continuous profit growth in 2 consecutive years, a positive cash flow from operating activities. Firm B in the Questionnaire is a firm with a negative profit and a negative cash flow from operating activities. Questionnaire No. 2 includes Firm $\mathrm{C}$ and $\mathrm{D}$, where Firm $\mathrm{C}$ has a positive profit which grows in 2 consecutive years, negative cash flow from operating activities and Firm D has a negative profit but positive cash flow from operation activities. The Questionnaire only provides information about operating cash flow in cash flow statements so that investors can focus on the relationship between cash flow and profitability of the firms. Moreover, the overview shows that cash flow from operating activities is a major factor in the firm's cash flow statement; giving too much information is unnecessary.

The survey questionnaire asks respondents' age, gender, educational background, investment term, etc. The US accounting regulations are used as reference to ascertain whether the investors' decision are affected by the information in the financial statements, According to Taylor, Anderson, and Sennetti (1987) and Norton and Wetzel (1986, 1984) a financial statement influences the decision of users of information when the information given by the statement is appropriate. The appropriateness of the information in the financial statements relies on the fact that the future forecast is based on the information provided by the firm in the present, and a feedback on whether the investment is good or not may be evaluate. The authors therefore asked two questions to evaluate the impact of the cash flow statement on their investment decisions based on the firm's future stock price projections. The first research question is about the investor's prediction about market impact on the firm's stock price. This is a predictive question about future stock prices. It is given by the authors to investors to evaluate how the stock price of the firm is, whether its stock price may increase in the following year. This is the market's perception of stock prices of these two firms. This is predictive in investment decisions.

Question 1: Do you think the firm's stock price will increase next year?

The second research question is about how investors feel about the firm's basic values. This research question is related to the perspective on how the firm will perform in the future, how an investor evaluates the corporate value. This research question is responsive to the investment.

Question 2: Do you think it is a good investment in this firm?

The questions are rated on a 5-point Likert scale from 1 to 5 , where 1 is "strongly disagree" and 5 is "strongly agree."

After responding to questions regarding the investor's decision in the case of Firm A, B, C and D, the authors ask investors four questions regarding familiarity and comfort of investors regarding their decisions. Questions relate to the difficulty in analyzing an investment, the time of the analysis, the ability to use conventional analytical techniques, and confidence in analyzing an investment. Based on the 5-point Likert scale, the authors compare two assessments on the comfort and confidence of investors with or without information from cash flows from business activities. If investors do experience difficulties or problems resulting in any lack of confidence in the business analysis, the information of cash flow statement is not really necessary for users since they do not find any matters.

The research on confidence in carrying out evaluations is widely made in those of Paese and Sniezek (1991). The 
research indicates that people's attitudes influence their decisions, and their consideration of whether information is needed. If users feel completely comfortable with their decisions despite the information contrasting with their view, the information in the financial statements is not really important to them. The investor's decision is based on familiarity of skill, knowledge in analysis, comfort and confidence in acknowledging the given information. The authors also ask if investors' confidence and comfort have changed when there are positive and negative information in the cash flow statement, i.e., operating cash flow. Questions about investor's attitude include:

Question 3: Is this investment more difficult to analyze than your previous investments?

Question 4: Does it take you more time to conduct an analysis of the financial situation in this firm compared to the previous analysis?

Question 5: With the above information, do you have sufficient knowledge and skills to carry out investment analysis?

Question 6: Are you sure about your analysis of the financial situation of the Firm?

In questions 3 and 4, the authors use a 5-point Likert scale to measure investors' response, where the higher points prove the more difficult and time spent in analyzing the financial statements of these firms, the lower the confidence and comfort of the investors in their decisions. In research questions 5 and 6 , the higher points prove the more confidence and comfort in their making decisions.

The questions of behavioral research are to find out the attitude of investors towards the information of profitability on the income statement and cash flow from operating activities of the business; when the business has a profit, whether the difference in cash flow from operating activities will affect the decision of the investor or not; or when the business has a negative profit, whether the difference of cash flow from operating activities will affect the decision of the investor or not.

\section{Results and Discussion}

The authors want to examine whether the investor's decision will change when there is opposite information about cash flow from positive and negative business activities. It will partly reflect the influence of the information in the cash flow statement to investors in their making decisions. The authors test the equality of the two mean values based on the information of two independent samples (Independent Samples T-test) for two independent groups of investors with almost similar information about profits from the business performance report, while information on the cash flows from operating activities are opposite. The Likert scale is numbered from 1 to 5 where 1 is the lowest rating and it moves to 5 as the higher the rating is.

Firstly, comparing firms having a positive profit, positive cash flow from operating activities and firms having a positive profit, but negative cash flow from operating activities. In this case, we will compare whether the stock price will increase and whether this investment is good or not.

A test on the equality of the two mean value is achieved from the information of two independent samples to assess whether the stock price of the firm will increase or decrease in the future and the investment in this firm is good or not. The mean value of evaluating the firm's stock price increase or decrease in the following year from positive operating activities is 4.14 and the negative cash flow from operating activities is 4.09.

In this case, the significant level of observation in the Levene test of equality of the two overall variances (Levene's test) is respectively $0.164>0.05$, so we will use the two equal variances assumed. The results are significant for these tests or not based on the significance level (sig) of the observation in the T-test for Equality of Means. For the first test of a change in the stock price that has a significant level of observation $(\mathrm{sig})=0.574>0.05$, the information from cash flow from operating activities does not affect the investors' evaluation of the firm's stock whether it will increase or decrease. Investors will not change individual decisions when there is more information on cash flow from operating activities. Evaluating investors' opinions on the increase of stocks in the case of positive profits, positive cash flow from operating activities for businesses and the case of positive profits, negative cash flow from operating activities, are shown in Table 1.

The second test evaluates whether the investment is good or not, as shown in Table 2, and has an observable significance (sig) in the Levene test of $0.921>0.05$, so we will use the result of the two equal variances assumed. The results for these tests are significant or not based on the significance level of the observation (sig) in the T-test for Equality of Means. The mean score for Firm A with a positive profit, positive cash flow from operating activities is 4.01; and for Firm $\mathrm{C}$ with a positive profit, negative cash flow from operating activities is 3.89 . In the second test we have the significance level in the observation $(\mathrm{sig})=0.174>0.05$, so it is unreasonable to say that information about cash flow from operating activities affects the perception of the investment. Evaluating investors' opinions on the investment in case of positive profits, positive cash flow from operating activities for businesses and the case of positive profit, negative cash flow from operating activities are shown in Table 2.

These two values of significance in the observation (sig) are both greater than the significance. Through two independent T-tests, it is found that there is not enough basis to reject the assumption that there is no difference in the investor's decisions if the opposite information in operating activities affects their decision when the firm has a positive profit. 
Table 1: Evaluating investors' opinions on the increase of stocks

\begin{tabular}{|c|l|c|c|c|c|}
\hline \multicolumn{1}{|c|}{ Group Statistics } \\
\hline & \multicolumn{1}{|c|}{ Group } & N & Mean & Std. Deviation & Std. Error Mean \\
\hline \multirow{2}{*}{ Points } & Positive profits, positive cash flow from operating activities & 80 & 4.14 & .590 & .066 \\
\cline { 2 - 7 } & Positive profits, negative cash flow from operating activities & 80 & 4.09 & .532 & .060 \\
\hline
\end{tabular}

\section{Independent Samples Test}

\begin{tabular}{|c|c|c|c|c|}
\hline & & & \multicolumn{2}{|c|}{ Points } \\
\hline & & & $\begin{array}{l}\text { Equal variances } \\
\text { assumed }\end{array}$ & $\begin{array}{c}\text { Equal variances } \\
\text { not assumed }\end{array}$ \\
\hline \multirow{2}{*}{ Levene's Test for Equality of Variances } & \multicolumn{2}{|l|}{$\mathrm{F}$} & 1.956 & \\
\hline & \multicolumn{2}{|l|}{ Sig. } & .164 & \\
\hline \multirow{7}{*}{ T-test for Equality of Means } & \multicolumn{2}{|l|}{$\mathrm{t}$} & .563 & .563 \\
\hline & \multicolumn{2}{|l|}{ df } & 158 & 156.365 \\
\hline & \multicolumn{2}{|l|}{ Sig. (2-tailed) } & .574 & .574 \\
\hline & \multicolumn{2}{|l|}{ Mean Difference } & .050 & .050 \\
\hline & \multicolumn{2}{|l|}{ Std. Error Difference } & .089 & .089 \\
\hline & \multirow{2}{*}{$\begin{array}{l}95 \% \text { Confidence Interval } \\
\text { of the Difference }\end{array}$} & -.125 & -.125 & -.132 \\
\hline & & .225 & .225 & .232 \\
\hline
\end{tabular}

Table 2: Evaluating investors' opinions on the investment

\begin{tabular}{|c|c|c|c|c|c|}
\hline \multicolumn{6}{|c|}{ Group Statistics } \\
\hline & Group & $\mathbf{N}$ & Mean & $\begin{array}{l}\text { Std. } \\
\text { Deviation }\end{array}$ & $\begin{array}{l}\text { Std. } \\
\text { Error } \\
\text { Mean }\end{array}$ \\
\hline \multirow{2}{*}{ Points } & $\begin{array}{l}\text { Positive profits, positive cash flow from } \\
\text { operating activities }\end{array}$ & 80 & 4.01 & .606 & .068 \\
\hline & $\begin{array}{l}\text { Positive profits, negative cash flow from } \\
\text { operating activities }\end{array}$ & 80 & 3.89 & .551 & .062 \\
\hline
\end{tabular}

\begin{tabular}{|c|c|c|c|c|}
\hline \multicolumn{5}{|c|}{ Independent Samples Test } \\
\hline & & & \multicolumn{2}{|c|}{ Points } \\
\hline & & & Equal variances assumed & Equal variances not assumed \\
\hline \multirow{2}{*}{$\begin{array}{l}\text { Levene's Test for } \\
\text { Equality of Variances }\end{array}$} & \multicolumn{2}{|l|}{$\mathrm{F}$} & .010 & \\
\hline & \multicolumn{2}{|l|}{ Sig. } & .921 & \\
\hline \multirow{7}{*}{$\begin{array}{l}\text { T-test for Equality of } \\
\text { Means }\end{array}$} & \multicolumn{2}{|l|}{$\mathrm{t}$} & 1.365 & 1.365 \\
\hline & \multicolumn{2}{|l|}{ df } & 158 & 156.605 \\
\hline & \multicolumn{2}{|l|}{ Sig. (2-tailed) } & .174 & .174 \\
\hline & \multicolumn{2}{|l|}{ Mean Difference } & .125 & .125 \\
\hline & \multicolumn{2}{|l|}{ Std. Error Difference } & .092 & .092 \\
\hline & \multirow{2}{*}{$\begin{array}{l}95 \% \text { Confidence Interval } \\
\text { of the Difference }\end{array}$} & Lower & -.056 & -.056 \\
\hline & & Upper & .306 & .306 \\
\hline
\end{tabular}


Secondly, testing the investor's decision in the case of negative profits, negative cash flow from operating activities and negative profits and positive cash flow from operating activities.

Regarding the change in the stock the mean value for negative profits, negative cash flow from operating activities in Firm B is 2.35, while for the negative profit and positive cash flow from operating activities in Firm D is 2.96. For the first test in the case of negative profit on the change in stock prices we have a significant level of observation (sig) $=0.000<0.05$, indicating there is a change in the evaluation of the increase or decrease of stock prices when there is an opposite information about the business cash flow. Assessing the opinions of investors on the increase of securities in the case of negative profits, negative cash flow from operating activities for businesses and the case of negative profits, positive cash flow from operating activities are presented in Table 3 .

Whether the investment is good or bad, the mean value of a firm with negative cash flow from operating activities is 2.28, while it is 2.93 , with information about positive cash flow from operating activities, which are shown in Table 4. This table evaluates investors' opinions on the investment in the case of negative profits, negative cash flow from operating activities for businesses and the case of negative profits, and positive cash flow from operating activities. In the test in the case of negative profit, whether the investment is good or bad, we also achieve a significant level of observation $(\mathrm{sig})=0.003<0.05$ which proves that there is also a change in investor perception when investors have an opposite information on operating cash flow compared to the case of negative profits and negative cash flow from operating activities. The perception of good or bad investment changes when the profit is negative and there is opposing information about positive operating cash flow (see Table 4).

Based on the two independent T-tests, it is found that there are sufficient grounds to reject the assumption that there is no difference in the investor's decision when the firm having a negative profit with opposing information of cash flow from operating activities. Thus, in the case of a negative profit, having positive information about the operating cash flow makes investors change their decisions.

Thirdly, assessing the comfort and confidence of investors in making decisions.

Although investors do not change their cash flow from operating activities, having opposing information from operating activities also affects their confidence in assessing their investments. The mean difficulty in assessing investments in the case of positive profits, positive cash flow from operating activities is 2.54 , while in the case of positive profits, negative cash flow from operating activities, it is 3.11. With the significance level of $0.000<0.05$, it is concluded that there is a difference in investors' confidence in both cases. Assessing investors' opinions on the difficulty in analyzing investments in case of positive profits, positive cash flow from operating activities for businesses with positive profits and negative cash flow from operating activities are presented in Table 5.

Table 3: Assessing the opinion of investors on the increase of securities

\begin{tabular}{|c|l|c|c|c|c|}
\hline \multicolumn{1}{|c|}{ Group Statistics } \\
\hline \multirow{2}{*}{ Points } & Noup & Mean & Std. Deviation & Std. Error Mean \\
\cline { 2 - 8 } & Negative profits, negative cash flow from operating activities & 80 & 2.35 & .597 & .067 \\
\cline { 2 - 8 } & Negative profits, positive cash flow from operating activities & 80 & 2.96 & .583 & .065 \\
\hline
\end{tabular}

\section{Independent Samples Test}

\begin{tabular}{|c|c|c|c|c|}
\hline & \multicolumn{2}{|c|}{ Points } \\
\hline & & & Equal variances assumed & Equal variances not assumed \\
\hline \multirow{2}{*}{$\begin{array}{l}\text { Levene's Test } \\
\text { for Equality of } \\
\text { Variances }\end{array}$} & \multicolumn{2}{|l|}{$\mathrm{F}$} & 8.968 & \\
\hline & \multicolumn{2}{|l|}{ Sig. } & .003 & \\
\hline \multirow{7}{*}{$\begin{array}{l}\text { T-test for Equality } \\
\text { of Means }\end{array}$} & \multicolumn{2}{|l|}{$\mathrm{t}$} & -6.561 & -6.561 \\
\hline & \multicolumn{2}{|l|}{ df } & 158 & 157.910 \\
\hline & \multicolumn{2}{|l|}{ Sig. (2-tailed) } & .000 & .000 \\
\hline & \multicolumn{2}{|l|}{ Mean Difference } & -.612 & -.612 \\
\hline & \multicolumn{2}{|l|}{ Std. Error Difference } & .093 & .093 \\
\hline & \multirow{2}{*}{$\begin{array}{l}95 \% \text { Confidence Interval } \\
\text { of the Difference }\end{array}$} & Lower & -.797 & -.797 \\
\hline & & Upper & -.428 & -.428 \\
\hline
\end{tabular}


Table 4: Evaluating investors' opinion on the investment

\begin{tabular}{|c|c|c|c|c|c|}
\hline \multicolumn{6}{|c|}{ Group Statistics } \\
\hline & Group & $\mathbf{N}$ & Mean & Std. Deviation & $\begin{array}{c}\text { Std. Error } \\
\text { Mean }\end{array}$ \\
\hline \multirow{2}{*}{ Points } & Negative profits, negative cash flow from operating activities & 80 & 2.28 & .616 & .069 \\
\hline & Negative profits, positive cash flow from operating activities & 80 & 2.93 & .632 & .071 \\
\hline
\end{tabular}

Independent Samples Test

\begin{tabular}{|c|c|c|c|c|}
\hline & & & \multicolumn{2}{|c|}{ Points } \\
\hline & & & Equal variances assumed & Equal variances not assumed \\
\hline \multirow{2}{*}{$\begin{array}{l}\text { Levene's Test for } \\
\text { Equality of Variances }\end{array}$} & \multicolumn{2}{|l|}{$\mathrm{F}$} & 2.222 & \\
\hline & \multicolumn{2}{|l|}{ Sig. } & .138 & \\
\hline \multirow{7}{*}{$\begin{array}{l}\text { T-test for Equality of } \\
\text { Means }\end{array}$} & \multicolumn{2}{|l|}{$\mathrm{t}$} & -6.589 & -6.589 \\
\hline & \multicolumn{2}{|l|}{ df } & 158 & 157.893 \\
\hline & \multicolumn{2}{|l|}{ Sig. (2-tailed) } & .000 & .000 \\
\hline & \multicolumn{2}{|l|}{ Mean Difference } & -.650 & -.650 \\
\hline & \multicolumn{2}{|c|}{ Std. Error Difference } & .099 & .099 \\
\hline & \multirow{2}{*}{$\begin{array}{l}95 \% \text { Confidence } \\
\text { Interval of the } \\
\text { Difference }\end{array}$} & Lower & -.845 & -.845 \\
\hline & & Upper & -.455 & -.455 \\
\hline
\end{tabular}

Table 5: Assessing investors' opinions on the difficulty in analyzing investments

\begin{tabular}{|c|l|r|r|r|r|}
\hline \multicolumn{1}{|c|}{ Group Statistics } \\
\hline \multirow{3}{*}{ Points } & \multicolumn{1}{|c|}{ Group } & \multicolumn{1}{|c|}{ N } & Mean & Std. Deviation & Std. Error Mean \\
\hline & $\begin{array}{l}\text { Positive profits, positive cash flow from operating } \\
\text { activities }\end{array}$ & $\begin{array}{l}\text { Positive profits, negative cash flow from operat- } \\
\text { ing activities }\end{array}$ & 81 & 2.54 & .636 \\
.072 \\
\hline
\end{tabular}

Independent Samples Test

\begin{tabular}{|c|c|c|c|c|}
\hline & & & \multicolumn{2}{|c|}{ Points } \\
\hline & & & Equal variances assumed & Equal variances not assumed \\
\hline \multirow{2}{*}{$\begin{array}{l}\text { Levene's Test for } \\
\text { Equality of Variances }\end{array}$} & \multicolumn{2}{|l|}{$\mathrm{F}$} & .750 & \\
\hline & \multicolumn{2}{|l|}{ Sig. } & .388 & \\
\hline \multirow{7}{*}{$\begin{array}{l}\text { T-test for Equality of } \\
\text { Means }\end{array}$} & \multicolumn{2}{|l|}{$\mathrm{t}$} & -5.401 & -5.406 \\
\hline & \multicolumn{2}{|l|}{ df } & 158 & 157.534 \\
\hline & \multicolumn{2}{|l|}{ Sig. (2-tailed) } & .000 & .000 \\
\hline & \multicolumn{2}{|l|}{ Mean Difference } & -.567 & -.567 \\
\hline & \multicolumn{2}{|c|}{ Std. Error Difference } & .105 & .105 \\
\hline & \multirow{2}{*}{$\begin{array}{l}95 \% \text { Confidence } \\
\text { Interval of the } \\
\text { Difference }\end{array}$} & Lower & -.774 & -.774 \\
\hline & & Upper & -.360 & -.360 \\
\hline
\end{tabular}


The average assessment results for the four firms shown in Table 6 is taken into account. For the first question about the difficulty of the analysis, investors' assessment on two positive profits, negative cash flow from operations and negative profit, positive cash flow from operating activities is more difficult than their assessment on two businesses, one with positive profits, positive cash flow from operating activities and the other having negative profits, negative cash flow from operating activities. This is similar to the authors' expectation because the given information is opposite negative profit whilst positive cash flow from operating activities and positive profit whilst negative cash flow from operating activities. The higher the mean, the more investors find it difficult to analyze. Compared with the negative profit and positive cash flow from operating activities, the mean is 3.36, which is greater than 3.11, the mean achieved in case of positive profits and negative cash flow from operating activities. This discrepancy shows that, when profits are negative, it is more difficult for investors to analyze than when profits are positive. In the case of positive profit and positive cash flow from operating activities, the mean is 2.54 while in case of negative profit and negative cash flow from operating activities the mean is 2.42 .

Similarly, regarding the research question about the time to analyze the investment, the scores of Firm B having a negative profit, negative cash flow from operating activities, Firm A having a positive profit, positive the cash flow from operating activities, Firm $\mathrm{C}$ having a positive cash flow from operating activities and Firm D having a negative profit and positive cash flow from operating activities is, respectively, $2.89 ; 3.03,3.43$ and 3.67 . Thus, in the two research questions, the lower the average score, the higher the level of confidence in the analysis.

However, for the latter two questions about the knowledge and skills to analyze the investment and the confidence level in analyzing the investment, the lower the score, the lower the confidence level. The opposing information between profit and cash flow from operating activities makes it harder for investors to use conventional analytical techniques and a lack of comfort in making their decisions (see Table 6).

\section{Conclusions and Recommendations}

\subsection{Conclusions}

Based on the authors' research, hypothesis $\mathrm{H} 1$ has been rejected. When there is no difference in the investors' decision in the case of a positive profit, the cash flow from operating activities differs positively and negatively. However, investors also feel that there is a lack of confidence in decision making in the case of a positive profit and a negative cash flow from operating activities. In hypothesis $\mathrm{H} 2$ it is seen that there is a difference in the investor's decision in the case of a negative profit, the cash flow from operating activities differs negatively and positively. Investors have changed individual decisions when there is conflicting information

Table 6: Evaluating investors' opinions on the comfort and confidence in assessing investments in businesses

\begin{tabular}{|l|c|c|c|c|}
\hline \multicolumn{1}{c|}{ Questions } & $\begin{array}{c}\text { Positive profit, } \\
\text { positive cash flow } \\
\text { from operating } \\
\text { activities of Firm A }\end{array}$ & $\begin{array}{c}\text { Negative profit, } \\
\text { negative cash flow } \\
\text { from operating } \\
\text { activities of Firm B }\end{array}$ & $\begin{array}{c}\text { Positive profit, } \\
\text { negative cash flow } \\
\text { from operating } \\
\text { activities of Firm C }\end{array}$ & $\begin{array}{c}\text { Negative profit, } \\
\text { positive cash flow } \\
\text { from operating } \\
\text { activities of Firm D }\end{array}$ \\
\hline $\begin{array}{l}\text { 1. This investment } \\
\text { is more difficult to } \\
\text { analyze than previous } \\
\text { investments }\end{array}$ & 2.54 & 2.42 & 3.11 & 3.36 \\
\hline $\begin{array}{l}\text { 2. Analyzing the financial } \\
\text { situation of this firm } \\
\text { takes more time than } \\
\text { previous firms }\end{array}$ & 3.03 & 2.89 & 3.43 \\
\hline $\begin{array}{l}\text { 3. With the above } \\
\text { information, do } \\
\text { you have sufficient } \\
\text { knowledge and skills } \\
\text { to perform investment } \\
\text { analysis? }\end{array}$ & 3.05 & 3.28 & 3.67 \\
\hline $\begin{array}{l}\text { 4. Certainty in analyzing } \\
\text { the financial situation } \\
\text { at this Firm }\end{array}$ & 3.44 & 3.67 & 3.21 & 2.85 \\
\hline
\end{tabular}


about cash flow from operating activities. In this case, it is also seen that investors take more into consideration when there is conflicting information on cash flow from operating activities than when both profit and cash flow from operating activities are negative.

\subsection{Recommendations}

The paper points out that investors are mainly concerned about the business performance report, which reflects the profits of a firm rather than the cash flows mostly mentioned in the cash flow statement from operating activities. When the corporate profits are positive and growth rate is stable, investors who make decisions are not affected by the information from the cash flow statement. Investors only pay attention to cash flow statements when corporate profits are not satisfactory. It is a mistake of investors in decision-making. The interest is in profit targets and high-profit generation to help businesses easier to call for investments. Therefore, the profit of the business is often adjusted by the management until it cannot be adjusted anymore. Cash flows from the firm's cash flow statements often reflect the weakness earlier than the business performance report. Investors who intend to make a long-term investment should pay attention to information on cash flow statements. Vietnam's stock market is perceived as an ineffective information market, where the information is not transparent. In newly-developed markets, any ineffective information or transparent and honest references to the information from the statements without being affected by accounting estimates such as cash flow statements are essential.

\section{References}

Aoun, D., \& Hwang, J. (2008). The effects of cash flow and size on the investment decisions of ICT firms: A dynamic approach. Information Economics and Policy, 20(2), 120-134.

Clinch, G., Sidhu, B., \& Sin, S. (2002). The Usefulness of Direct and Indirect Cash Flow Disclosures. Review of Accounting Studies, 7(4), 383-404/ https://link.springer.com/ article/10.1023/A:1020759511460.

Dickinson, V. (2011). Cash Flow Patterns as a Proxy for Firm Life Cycle. The Accounting Review, 86(6), 1969-1994. https://doi. org/10.2308/accr-10130.

Gomez, L. (2002). Enron - A Case for Better Understanding of Cash Flows. Business Credit, 104, 12-13.

Imhof, M., \& Seavey, S. (2018). How investors value cash and cash flows when managers commit to providing earnings forecasts. Advances in Accounting, 41, 74-87. https://doi.org/10.1016/j. adiac.2018.03.004.

Jooste, L. (2011). Measuring performance by means of income and cash flows and the life-cycle theory. The Business Review, Cambridge, 19(1), 179-186.
Kallunki, J.-P., \& Paakki, E. (2005). Stock market response to IFRS/IAS cash flows. SSRN Electronic Journal, 1-25. DOI: $10.2139 /$ ssrn.871029.

Lau, W. T., \& Mahat, F. B. (2019). Robustness of Cash Flow Value: Investment in ASEAN. Journal of Asian Finance, Economics and Business, 6(2), 247-255. doi:10.13106/jafeb.2019.vol6.no2.247.

McEnroe, J. (1996). An examination of attitudes involving cash flow accounting: Implications for the content of cash flow statements. The International Journal of Accounting, 31(2), 161-174. https://doi.org/10.1016/S0020-7063(96)90002-3.

Melander, O., Sandström, M., \& Schedvi, E. V. (2017). The Effect of Cash Flow on Investment: An Empirical Test of the Balance Sheet Theory. Empirical Economics, Springer, 53(2), 695-716, DOI: 10.1007/s00181-016-1136-y.

Miranda-Lopez, J., \& Nichols, L. (2012). The use of earnings and cash flows in investment decisions in the U.S. and Mexico. Experimental evidence Journal of International Accounting, Auditing and Taxation, 21(2), 198-208.

Mumtaz, A., Saeed, T., \& Ramzan, M. (2018). Factors affecting investment decision-making in Pakistan stock exchange. International Journal of Financial Engineering, 05(04), 1-14. DOI: $10.1142 / \mathrm{s} 2424786318500330$.

Neill, J. D., Schaefer, T. F., Bahnson, P. R., \& Bradbury, M. E. (1991). The Useful of Cash Flow Data: A Review and Synthesis. Journal of Accounting Literature, 10(1), 117-150.

Nguyen, D. D., \& Tran, T. T. (2014). Discussion methods of statement of cash flows in companies listed on the stock market in Vietnam. Journal of Economics and Development, 2014(II), 69-77.

Nguyen, D. V., Dang, Q. D., \& Pham, H. G. (2020). Influence of Overconfidence and Cash Flow on Investment in Vietnam. Journal of Asian Finance, Economics and Business, 7(2), 99106. doi:10.13106/jafeb.2020.vol7.no2.99.

Nguyen, T. T. (2016, 12 16). Investor sentiment in Vietnam financial market. (Agency of the State Bank of Vietnam). Retrieved December 10 2019, from Banking Review website: http://tapchinganhang.gov.vn/tam-ly-nha-dau-tu-tren-thitruong-tai-chinh-viet-nam.htm

Norton, C., \& Wetzel, T. (1986). The recognition and measurement guidelines of FASB concepts no. 5. Journal of Accounting Education, 4(2), 75-84. https://doi.org/10.1016/07485751(86)90008-4.

Oh, H. M., \& Shin, H. Y. (2019). A Study on the Relationship between Analysts' Cash Flow Forecasts Issuance and Accounting Information: Evidence from Korea. Sustainability, 1-26. doi:10.3390/su11123399.

Paese, P., \& Sniezek, J. (1991). Influences on the appropriateness of confidence in judgment: Practice, effort, information, and decision-making. Organizational Behavior and Human Decision Processes, 48(1), 100-130. https://doi. org/10.1016/0749-5978(91)90008-H

Passionate investment. (2019). Why is securities investment in Vietnam so risky and risky? (Passionate investment). Retrieved 
January 1, 2020, from http://pif.vn/vi-sao-dau-tu-chung-khoano-viet-nam-lai-vo-cung-rui-ro-va-mao-hiem/

Rasheed, M. H., Rafique, A., Zahid, T., \& Akhtar, M. W. (2018). Factors influencing investor's decision making in Pakistan: Moderating the role of locus of control. Review of Behavioral Finance, 10(1), 70-87. https://doi.org/10.1108/RBF.

Schellenger, M., \& Cross, J. N. (1994). FASB 95, Cash Flow and bankruptcy. Journal of Economics and Finance, 18(3), 261274. Retrieved from https://ssrn.com/abstract=6209.

Taylor, B., Anderson, L., \& Sennetti, J. (1987). SFAC no. 2 reliability from a statistical perspective. Journal of Accounting
Education, 5(2), 315-321. https://doi.org/10.1016/07485751(87)90027-3.Ward, T., \& Foster, B. (1997). A Note on Selecting a Response Measure for Financial Distress. Journal of Business Finance and Accounting, 24(6), 869-879. https://doi.org/10.1111/1468-5957.00138.

Yeo, H.-J. (2018). Role of free cash flows in making investment and dividend decisions: The case of the shipping industry. The Asian Journal of Shipping and Logistics, 34(2), 113-118. http://dx.doi.org/10.1016/j.ajsl.2018.06.007.

Zager, K., \& Zager, L. (2006). The role finacial information in decision making process. Innovative Marketing, 2(3), 35-40. 